Relations industrielles

Industrial Relations

\title{
Steven H. London, Elvira R. Tarr and Joseph F. Wilson, eds. The Re-Education of the American Working Class
}

\section{Sidney H. Ingerman}

Volume 47, numéro 3, 1992

URI : https://id.erudit.org/iderudit/050801ar

DOI : https://doi.org/10.7202/050801ar

Aller au sommaire du numéro

Éditeur(s)

Département des relations industrielles de l'Université Laval

ISSN

0034-379X (imprimé)

1703-8138 (numérique)

Découvrir la revue

Citer ce compte rendu

Ingerman, S. H. (1992). Compte rendu de [Steven H. London, Elvira R. Tarr and Joseph F. Wilson, eds. The Re-Education of the American Working Class].

Relations industrielles / Industrial Relations, 47(3), 584-585.

https://doi.org/10.7202/050801ar

Tous droits réservés @ C Département des relations industrielles de l'Université Laval, 1992
Ce document est protégé par la loi sur le droit d'auteur. L'utilisation des services d'Érudit (y compris la reproduction) est assujettie à sa politique d'utilisation que vous pouvez consulter en ligne.

https://apropos.erudit.org/fr/usagers/politique-dutilisation/ 
The book is well written for the general reader by a number of authors within a general framework designed by the editors. The editors' chapters are especially well written; they present the main argument of the book with some passion. The book is recommended for the general reader interested in a labour perspective on social issues in the 1990s. It may also be useful as a set of readings for students in labour history or social issues courses at the university level.

Terry Hercus

The University of Manitoba

The Re-Education of the American Working Class, by Steven $\mathrm{H}$. London, Elvira R. Tarr and Joseph F. Wilson, eds., New York, Greenwood Press, 1990, 288 p., ISBN 0-313-26785-5, ISSN 0886-8239 (Lib. of Congress Catalog Card)

This is a rare and valuable book that primarily deals with educational programs for unionized workers in the United States. It is rare because of the paucity of academic attention that has been devoted to this subject in North America, and it is valuable because understanding the evolution of worker education, in all it varied forms, is intimately related to understanding the role of the labour movement in social and economic development. It also raises uncomfortable questions about the class character of post-secondary education.

The twenty-two papers that make up the book are previously unpublished works many of which were presented at a 1987 conference on Labor Education and Educating Labour which was held at Brooklyn College's Graduate Center for Worker Education, City University of New York. Some of the papers were solicited by the editors during the two years following the conference. The foreword to the book by Joseph S. Murphy, chancellor of the City University of New York, describes the need for the contributions in the book in terms of the waning influence of labour education after World War II, and the progressive disengagement of the universities from "nonelite causes and aspirations". $\mathrm{He}$ maintains that "[w]hat higher education ... created was a system of class differentiation that perfectly suited powerful economic interests: A middle class technically trained to fill corporate needs but largely unconcerned with the philosophic underpinnings of corporate society - and a working class economically powerless and intellectually unequipped to ask why". He, therefore, sees this volume as a stop towards reasserting the aspirations of that vast part of the population made up of workers and, at the same time, revalidating the social role of education in society.

There are a number of major themes that underlie many of the articles in this book. These include the effects of the tertiarization of employment on the demands for labour education, the implications of new technology for worker training, and the educational issues surrounding the growing importance of women in the labour force. Two important contributions deal with education and racism. There is also a recognition of the striking decline in United States union density rate in recent decades. Many of the contributors see new approaches to 
labour education as playing a role in stemming this decline and as an instrument for attracting new members. A number of the contributors see new approaches to labour education as an important element in rejuvenating a divided and dispirited American society. volume.

An excellent bibliographical essay on worker education concludes the

At least two weaknesses can be noted in this collection of articles. The first is the disproportionate number of articles by authors whose activities are centered in the Northeastern part of the United States and who write from the perspective of that region. The second is the paucity of international comparisons of United States experience in labour education with that of other developed industrial countries. There is a single brief article on worker education in Western Europe. The absence of material on labour education in Canada is unfortunate. Given the historical ties between the Canadian and the United States labour movements, the high degree of economic integration of the neighboring countries, and the striking difference between the relatively stable Canadian union density rate and the declining United States rate, the book would have benefited from a study of the broad network of labour education programs in Canada with its summit in the twenty-five year old Labour College of Canada.

Sidney H. INGERMAN

McGill University

La rédaction du contrat individuel de travail: pourquol et comment, par Ronald Sirard avec la participation de Claire Armstrong, Montréal, Wilson \& Lafleur Ltée, 1990, 126 p., ISBN 2-89127-179-3

Ce volume se divise en deux parties, comme son titre le laisse entrevoir.

En premier lieu, les auteurs veulent nous expliquer "pourquoi» rédiger un contrat individuel de travail. Ce contrat étant consensuel, on peut se demander quelle est l'utilité d'un écrit qui le constate.

Il y a deux raisons qui militent en faveur de la rédaction d'un écrit. La première raison est que l'écrit valablement fait, c'est-à-dire dont la formation ou la validité ne sont pas contestées, ne peut être contredit par témoignage ou autrement. L'écrit constitue donc le moyen de preuve par excellence, en cas de litige futur.

L'autre raison a trait à la nécessité de préciser les droits et obligations de chaque partie. Ainsi, l'obligation de fournir une prestation de travail convenable étant un élément essentiel du contrat, il est inutile de le mentionner, sauf précisément lorsque l'employeur s'attend à un rendement exceptionnel. En cas d'exécution déficiente, l'employeur pourra, grâce à l'écrit, se départir plus facilement des services du salarié car ce document lui fournira une défense utile à la contestation d'un renvoi sous forme de poursuite en dommages et intérêts ou de réclamation de salaire d'échéance en échéance. En d'autres mots, il lui sera plus aisé de faire la preuve requise pour la résolution judiciaire de contrat préalablement résilié unilatéralement: le noeud du litige, en pareil cas, est 